\title{
Photosensitization of albino rats fed on lucerne-protein concentrate
}

\author{
By EVELYN LOHREY,* B. TAPPER AND E. L. HOVE \\ Applied Biochemistry Division, DSIR, \\ Palmerston North, New Zealand
}

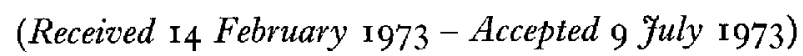

\begin{abstract}
I. The photosensitizing effect of leaf-protein concentrate (LPC) prepared from lucerne (Medicago sativa) was demonstrated when it was included in the diet of albino rats at concentrations between 40 and $480 \mathrm{~g} / \mathrm{kg}$ diet.

2. Skin lesions of varying severity up to the sloughing of ears and tails occurred when such rats were illuminated with natural daylight through window-glass or with simulated daylight from a bank of lamps having emission maxima at 410,437 and $660 \mathrm{~nm}$ and with approximately $4 \%$ of the energy of surmmer sunlight.

3. Protein concentrates prepared from ryegrass (Lolium multiforum) and a crude chlorophyll extract of spinach (Spinacea oleracea) did not cause these effects.

4. Extracts from blood plasma and livers of rats given lucerne L.PC contained pheophorbide- $a$ and two other unidentified green pigments, but no detectable phylloerythrin or chlorophyll. Extracts from the blood of rats given ryegrass LPC had no detectable pheophorbide or other chlorophyll-derived pigments.

5. The lucerne LPC given to the rats contained relatively large amounts of pheophorbide- $a$ among a variety of pigments. The ryegrass LPC and the spinach extracts had only small amounts of this pigment relative to the other chlorophyll-type pigments.

6 . These findings indicate that pheophorbide- $a$ and related pigments are the agents responsible for the photosensitization of the rats. Possible explanations of their presence in lucerne LPC are discussed.
\end{abstract}

In the course of a feeding trial to evaluate the safety of lucerne leaf-protein concentrate (LPC) (Hove, Lohrey, Urs \& Allison, 1974) a photosensitizing effect was noticed in albino rats exposed to daylight through a window. The severity of the skin lesions, up to final sloughing of ears and tails, was inversely correlated with distance from the window and, since direct sunlight did not enter, it was obvious that a potent sensitizing agent was involved.

It is the purpose of this paper to extend and quantify this effect and to report on studies of the nature of the causative factors.

There have been occasional reports of photosensitivity in animals grazing lucerne and clover. Literature on veterinary toxicology (e.g. Radeliff, 1964) refers to this as 'trefoil dermatitis'. The subject has been reviewed by Blum (I94I) and Clare (I952), but the causative agent has not been identified. Some 20 years ago Clare (1952) found that air-dried millet (Panicum miliacium) strongly photosensitized albino rats, whereas extracts of fresh millet and other chlorophyll extracts did not. He fractionated dried millet pigments and found that the photosensitizing agent for rats was associated with the pheophorbide fraction (N. T. Clare, personal communication).

Another possibility was that phylloerythrin, which is the active photosensitizing agent in facial eczema of sheep (Clare, I944; Done, Mortimer \& Taylor, I960), might

* Seconded from the New Zealand Dairy Research Institute, Palmerston North, New Zealand. 
be formed and absorbed in the intestines of rats given chlorophyll and related pigments at high concentrations. This could result in phylloerythrinaemia and the primary photosensistization of our rats even though they had normal livers (Hove et al. 1974). Therefore we looked initially for phylloerythrin in the blood and livers of our rats but found none; we did, however, find other pigments, one of which was tentatively identified as pheophorbide- $a$.

\section{EXPERIMENTAL}

\section{Animals and diets}

Weanling albino rats were obtained from the Small Animal Research Unit of Massey University. The adult male rats used were albino rats which had completed 5 months on the experimental diets in studies reported by Hove et al. (1974).

The diets for rats were those described by Hove et al. (r974). Variations of these diets were based on changes in the source of protein; casein was added at the expense of starch to supply protein at $100 \mathrm{~g} / \mathrm{kg}$ diet in those instances in which the product under test did not contribute at least this amount. Four batches of lucerne LPC were prepared and used at different times during the $197^{\mathrm{I}-2}$ season (Hove $e t$ al. 1974). These were compared with a commercial sample of lucerne LPC marketed under the trade-name X-Pro (Batley-Janss Enterprise Inc., Brawley, California). Two other leaf-protein concentrates were tested: one was made from lucerne (Medicago sativa, L. var. Wairau) without the addition of potassium metabisulphite, and the other was made from ryegrass (Lolium multiflorum Lam. var. Grasslands Tama Westerwolds). Crude chlorophyll extracts from green leaves of silver beet (Beta vulgaris) and spinach (Spinacea oleracea), prepared by the method of Strain \& Svec (I966), were also tested.

\section{Experimental procedures}

Illumination. Artificial light was provided by a battery of lamps made up of two Philips $15 \circ \mathrm{W}$ tungsten flood lights and one Philips $400 \mathrm{~W}$ HPLR lamp. These light sources did not emit u.v. radiation. The emission maxima were at wave-lengths $4 \mathrm{IO}$, $437,540,560$ and $600 \mathrm{~nm}$. The intensity of the light at $\mathrm{x} \cdot 2 \mathrm{~m}$ was $\mathrm{x} 6 \mathrm{~W} / \mathrm{m}^{2}$, or approximately $4 \%$ of the energy of peak summer sunlight at latitude $40^{\circ}$. Illumination time was $3-6 \mathrm{~h}$ daily, $7 \mathrm{~d} /$ week. Food cups and water bottles were removed during illumination to avoid shading the rats. Usually three rats were housed in one cage. The maximum temperature in the cage was $26^{\circ}$. Control rats, which were given diets containing casein as the only source of protein, were similarly illuminated. Ordinary artificial lighting in the animal room was left on during the day since this had no photosensitizing effect; the animal room was windowless.

Evaluation of lesions. A system of rating of the lesions was developed in order to compare the responses of groups of rats given different protein sources. Illumination of photosensitized rats affected any exposed surface of the body. Signs were observed most frequently on the ears, tail, back and paws; only rarely were the eyelids and snout affected.

The rating was on a $0_{-4}$ scale of severity for the four most commonly affected areas, 
giving a maximum score of 16 for individual rats. The total score for each group was divided by the number of rats to give the average group score.

The location and severity of the lesions on the animals was undoubtedly affected by their obvious discomfort under illumination; the averted heads and huddled posture resulted in the most severe lesions occurring on tails and backs.

The first signs were slight redness and oedema of the affected parts. This was followed by exudation of serous fluid, especially on the dorsal surface of the tail (grade $x$ ). This progressed to open sores (grade 2 ), usually starting at the base of the tail and at times covering the complete dorsal surface. This was followed by scab formation and distortion (grade 3 ). In some instances the exudation fluid phase was followed by blackening (with or without scab formation), commencing at the tip of the tail and progressing various distances up it. When this necrosis was complete the tail was sloughed off (grade 4).

The first effect on ears after the colour change and oedema was a blackening of the rims (grade I). This necrosis proceeded inward until the entire ear was black and stiff. The ears then disintegrated and were sloughed off (grade 4) (P1. I). The middle of the back was usually affected with loss of hair before sore and scab formation. The skin became thick and fibrous. Scab and sore formation was most often seen on the hind rather than front paws as they were more exposed to illumination.

Other signs of photosensitization included irritation and apparent pain on being touched. The effect of lesion development on the growth rate was obvious during the first 7-ro d and correlated with severity. However, except in very severe cases, growth rates quickly returned to normal, even under continued illumination. Lesions quickly healed after cessation of exposure to light, and the animals were normal except for the anatomical disfigurements they had suffered.

Extraction of pigments from blood plasma and liver. Rats were anaesthetized with diethyl ether, and blood samples were taken by cardiac puncture into a heparinized syringe. The blood was centifuged, and $5 \mathrm{ml}$ plasma were shaken with portions of diethyl ether and acetic acid mixtures as described by Perrin (r958) for the extraction of phylloerythrin. Analar reagents were used as recommended by Perrin; the diethyl ether was freshly distilled over hydrated ferrous sulphate before use. The pigments were partitioned into small portions of $5.5 \mathrm{M}-\mathrm{HCl}$ and then into diethyl ether after neutralization of the excess acid with alkaline sodium acetate (sodium acetate 0.9 mol/l, sodium hydroxide $1 \cdot 5 \mathrm{~mol} / \mathrm{l})$. These diethyl ether extracts were examined by visible-u.v. spectrophotometry.

About $30 \mathrm{~g}$ of pooled frozen liver were homogenized in a Virtis 45 homogenizer in $100 \mathrm{ml}$ of ethyl acetate-acetic acid $(4: \mathrm{r}, \mathrm{v} / \mathrm{v})$ and filtered, and the residue was washed with a further three $40 \mathrm{ml}$ portions of solvent mixture. The combined extract was washed with four $50 \mathrm{ml}$ portions of sodium acetate $(30 \mathrm{~g} / \mathrm{l})$ and $50 \mathrm{ml}$ of $0.2 \mathrm{M}-\mathrm{HCl}$ to remove porphyrins soluble in very dilute acid, and was then extracted four times with ro $\mathrm{ml}$ portions of $5.5 \mathrm{M}-\mathrm{HCl}$. The acid extract was neutralized to $\mathrm{pH} 3.5$ by the addition of solid sodium acetate before the pigments were partitioned into $40 \mathrm{ml}$ of ethyl acetate-light petroleum (b.p. $\left.80-100^{\circ}\right)(\mathrm{I}: \mathrm{I}, \mathrm{v} / \mathrm{v})$. This solvent extract was washed with a small amount of water to remove traces of acid. 
Table I. Photosensitivity lesions in weanling male and female and adult male albino rats given diets containing different batches of lucerne leaf-protein concentrates (LPC) (LPC-I to IV), X-Pro (a commercial sample of lucerne LPC), ryegrass $L P C$, or two crude chlorophyll extracts of green leaves, under simulated daylight illumination

(Adult male rats were uscd only for the first group of the fourth batch (IVa) of lucerne LPC)

\begin{tabular}{|c|c|c|c|c|c|c|c|}
\hline \multirow[b]{3}{*}{ Test material } & \multirow{2}{*}{\multicolumn{2}{|c|}{ Dictary content $(g / \mathrm{kg})$}} & \multicolumn{2}{|c|}{$\begin{array}{l}\text { Cumulative time } \\
\text { of illumination } \\
\text { (h) required } \\
\text { for }\end{array}$} & \multirow{3}{*}{$\begin{array}{l}\text { No. of rats } \\
\text { with lesions } \\
\text { total no. } \\
\text { of rats }\end{array}$} & \multirow{2}{*}{\multicolumn{2}{|c|}{$\begin{array}{c}\text { Mean score } \\
\text { of lesionsi } \\
\text { rat }\end{array}$}} \\
\hline & & & \multirow{2}{*}{$\begin{array}{l}\text { First } \\
\text { lesion }\end{array}$} & \multirow{2}{*}{$\begin{array}{l}\text { Maximum } \\
\text { lesion }\end{array}$} & & & \\
\hline & Test material & Protein & & & & 0 & q \\
\hline Lucerne LPC-I & $\begin{array}{l}320 \\
160\end{array}$ & $\begin{array}{l}200 \\
100\end{array}$ & $\begin{array}{l}\text { I5 } \\
\text { I5 }\end{array}$ & $\begin{array}{l}46 \\
46\end{array}$ & $\begin{array}{l}6 / 6 \\
6 / 6\end{array}$ & $\begin{array}{l}5 \\
5\end{array}$ & $\begin{array}{r}13 \\
8\end{array}$ \\
\hline Lucerne L.PC-II & $\begin{array}{r}160 \\
80 \\
40\end{array}$ & $\begin{array}{l}100 \\
100 \\
100\end{array}$ & $\begin{array}{l}15 \\
15 \\
15\end{array}$ & $\begin{array}{l}41 \\
56 \\
56\end{array}$ & $\begin{array}{l}3 / 3 \\
2 / 3 \\
2 / 3\end{array}$ & $\begin{array}{l}4 \\
2 \\
2\end{array}$ & - \\
\hline $\begin{array}{l}\text { Lucerne LPC-III } a \\
\qquad I I b^{*}\end{array}$ & $\begin{array}{l}160 \\
160\end{array}$ & $\begin{array}{l}100 \\
100\end{array}$ & $\begin{array}{l}24 \\
24\end{array}$ & $\begin{array}{l}6 I \\
6 I\end{array}$ & $\begin{array}{l}5 / 5 \\
6 / 6\end{array}$ & $\begin{array}{l}2 \\
5\end{array}$ & - \\
\hline $\begin{array}{r}\text { Lucerne L.PC-IV } a \\
\text { IV } b\end{array}$ & $\begin{array}{l}480 \\
160\end{array}$ & $\begin{array}{l}300 \\
100\end{array}$ & $\begin{array}{l}83 \\
24\end{array}$ & $\begin{array}{r}97 \\
117\end{array}$ & $\begin{array}{l}2 / 3 \\
3 / 3\end{array}$ & $\begin{array}{r}\mathbf{T} \\
\text { IO }\end{array}$ & - \\
\hline X-Pro & 280 & 100 & 65 & 82 & $6 / 8$ & $x \cdot 5$ & - \\
\hline Ryegrass LPC & I60 & 100 & - & x $26 \uparrow$ & $0 / 6$ & 0 & $\longrightarrow$ \\
\hline $\begin{array}{l}\text { Crude chlorophyll } \\
\text { extract of silver- } \\
\text { beet leaves }\end{array}$ & ro & 100 & $\mathrm{r} 7$ & 86 & $1 / 3$ & 2 & \\
\hline $\begin{array}{l}\text { Crude chlorophyll } \\
\text { extract of spinach } \\
\text { leaves }\end{array}$ & 20 & 100 & - & $82 \dagger$ & $0 / 6$ & o & - \\
\hline
\end{tabular}

Visible-u.v. absorption spectra were recorded with a Unicam SP 500 spectrophotometer and the pigment solutions were concentrated under reduced pressure before further analysis by thin-layer chromatography (TLC).

Extraction of pigments from LPC. Small portions $(0.2 \mathrm{~g})$ of each of the finely ground LPC were extracted by shaking with $5 \mathrm{ml}$ acetone or acetone-water $(80: 20$, $\mathrm{v} / \mathrm{v}$ ) for at least $20 \mathrm{~h}$ at $15^{\circ}$ in the dark. These extracts were examined by TLC.

Quantitative values for total pigments with the phytyl side-chain (chlorophylls +pheophytins), and for those without the phytyl side-chain (chlorophyllides + pheophorbides), were estimated as follows: $0.2 \mathrm{~g}$ portions of LPC were extracted by shaking for at least $20 \mathrm{~h}$ at $x 5^{\circ}$ in the dark with $5 \mathrm{ml}$ of a solution of oxalic acid hydrate ( $\mathrm{rog} / \mathrm{l}$ ) dissolved in acetone-water $(90: \mathrm{IO}, \mathrm{v} / \mathrm{v}$ ). The oxalic acid solution removed magnesium from those pigments in which it occurred. The pheophytins and pheophorbides were separated by TLC using cellulose (Bacon, 1965 ) and were eluted with ethyl acetate from the areas of cellulose corresponding to $R_{F}$ values reported by Bacon. The amounts of the eluted pigments were estimated by means of extinction 


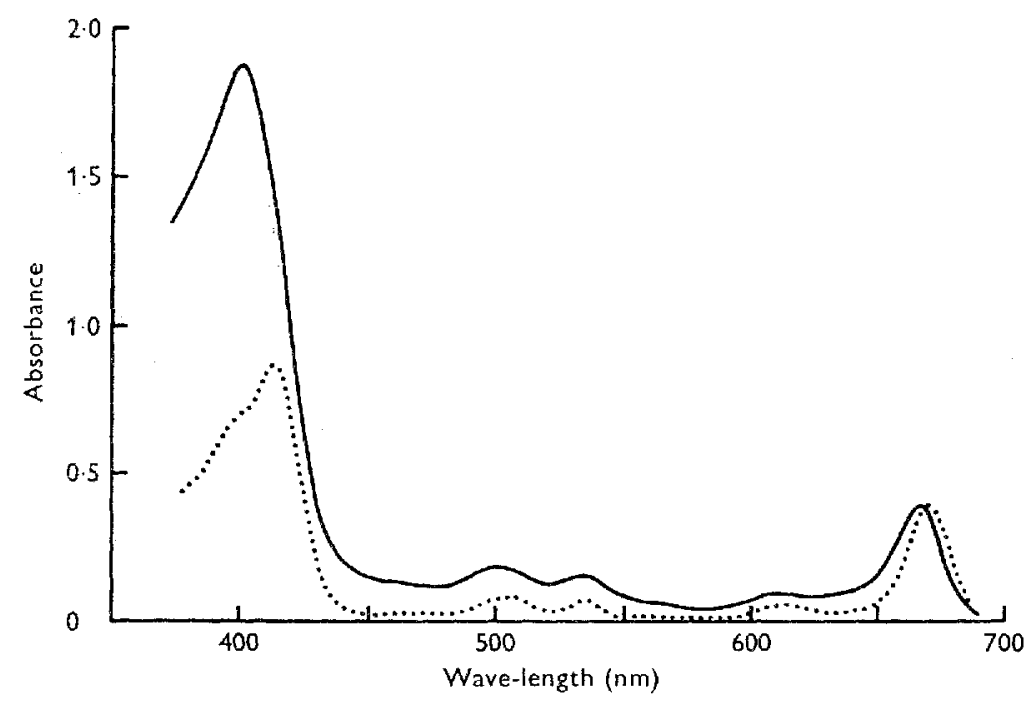

Fig. I. Absorption spectra of pheophorbide- $a$ dissolved in benzene (.....) and of the partly purified pigments from the plasma of a photosensitive rat given a diet containing lucerne leaf-protein concentrate (-). The plasma pigments were dissolved in $0.5 \mathrm{ml}$ diethyl ether and a $1 \mathrm{~cm}$ path-length cell was used.

coefficients for pheophytins- $a$ and $-b$ at $667 \mathrm{~nm}$ and $655 \mathrm{~nm}$, respectively, reported by Smith \& Benitez (1955).

Thin-layer chromatography. Extracts were chromatographed on cellulose thin-layer plates (MN-300; Macherey-Nagel Co.) or on commercially prepared sheets (Polygram Cel 300 ; Macherey-Nagel Co.) with light petroleum (b.p. $80^{\circ}-100^{\circ}$ )-acetonepropan-I-ol $(90: 10: 0 \cdot 45, \mathrm{v} / \mathrm{v})$ as the developing solvent. The major pigments were identified by comparing $R_{F}$ values with those reported by Bacon ( 1965 ) and by comparing the visible-light absorption spectra of the spots or bands in either ethyl acetate or acetone with published spectra (e.g. Smith \& Benitez, 1955). A small amount of pheophorbide- $a$ extracted from rat plasma and liver was tentatively identified by its $R_{F}$ value and by its absorption spectrum obtained by mounting the portion of a thinlayer sheet containing the spot in the Unicam SP 500 spectrophotometer light beam near the detector tube. It was compared with a similar sample prepared direct from lucerne LPC.

\section{RESULTS}

\section{Development of lesions}

The response to illumination of rats given different sources of LPC and chlorophyll extracts is presented in Table $r$. The hours of illumination refer to the cumulative periods of time between the commencement of illumination and the appearance of the first signs of photosensitivity, and secondly, the stage when signs appeared to be at a maximum. It is evident that all four batches of the lucerne LPC prepared during the year resulted in lesions when the rats were illuminated. Potassium metabisulphite was added in the preparation of all batches of lucerne LPC except batch III $b$; its absence had little effect on the development of lesions. 


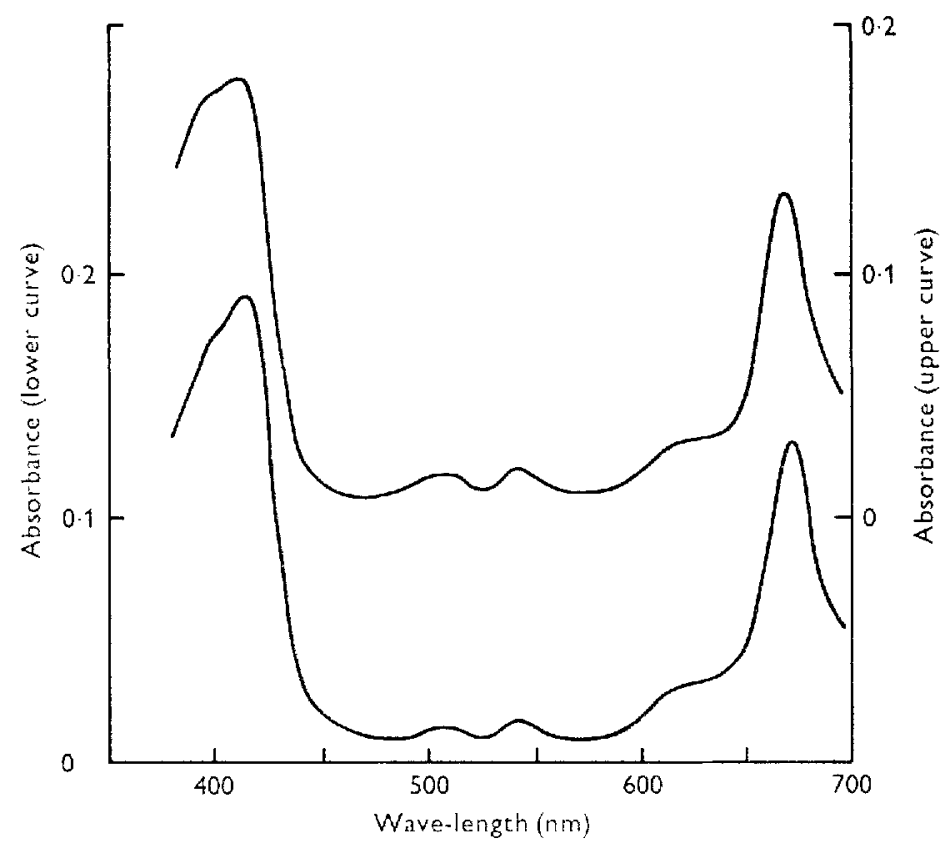

Fig. 2. Absorption spectra of pheophorbice- $a$ from lucerne leaf-protein concentrate (LPC) (lower curve) and from the blood plasma of a photosensitive rat (upper curve), recorded direct from the cellulose thin-layer sheet.

The commercial lucerne LPC (X-Pro) produced photosensitivity in rats but to a much lesser extent than our lucerne LPC. No signs were observed in rats given diets containing ryegrass LPC (prepared by the same method as the lucerne LPC) or in those given the crude chlorophyll extract of spinach leaves $(20 \mathrm{~g} / \mathrm{kg} \mathrm{diet})$, or in those given diets containing casein.

Of the animals examined, adult rats were much less susceptible than weanlings.

The lowest amount of lucerne LPC that would produce lesions was not established, but even at $40 \mathrm{~g} / \mathrm{kg}$ diet photosensitization occurred.

\section{Plasma and liver pigments}

The diethyl ether extracts of blood plasma of rats given the lucerne LPC were pale green in colour and gave strong orange-red fluorescence under near u.v. light. Extracts of blood plasma from animals receiving ryegrass LPC or casein were colourless and only weakly fluorescent. Comparison of the visible-light absorption spectra showed that the green solutions had absorption peaks at $400 \mathrm{~nm}$ and $666 \mathrm{~nm}$ and the peak height ratios were about $5: 1$. Smaller peaks were present at about $502 \mathrm{~nm}$ and $535 \mathrm{~nm}$. A typical spectrum is shown in Fig. I. Spectra of extracts from livers and plasma of the rats given lucerne LPC were similar.

TLC examination of concentrated extracts of plasma and liver gave a grey-green band with an $R_{F}$ of 0.20 in light petroleum (b.p. $80^{\circ}-100^{\circ}$ )-acetone-propan-I-ol $(90: 10: 0 * 45, \mathrm{v} / \mathrm{v})$ which was the same as that for a preparation of pheophorbide- $a$ from lucerne LPC. The absorption spectra of these bands cxamined direct on the 
Table 2. Amounts of the principal pigments with a phytyl group (chlorophylls + pheophytins) and without a phytyl group (chlorophyllides + pheophorbides) in leaf-protein concentrates (LPC) from lucerne and ryegrass.

\begin{tabular}{|c|c|c|c|c|}
\hline \multirow[b]{2}{*}{ Source of LPC } & \multicolumn{4}{|c|}{ Amount in LPC $(\mu \mathrm{mol} / \mathrm{g})$} \\
\hline & Pheophytin- $a$ & Pheophytin- $b$ & Pheophorbide- $a$ & Pheophorbide- $b$ \\
\hline Lucerne & $2 \cdot 8$ & Trace & $7 \cdot 5$ & Trace \\
\hline $\begin{array}{l}\text { Lucerne, without addition } \\
\text { of potassium metabisulphite }\end{array}$ & $8 \cdot 6$ & $3^{\cdot \mathbf{I}}$ & $5 \cdot 8$ & $1 \cdot 5$ \\
\hline X-Pro* & 0.6 & Trace & $2 \cdot 2$ & Trace \\
\hline Ryegrass & $12 \cdot 3$ & $3 \cdot 3$ & 0.9 & Trace \\
\hline
\end{tabular}

cellulose thin-layer sheet are shown in Fig. 2. Small amounts of two or three other green pigments were usually observed; one of them ran near the solvent front and the others were of lower $R_{F}$ than pheophorbide- $a$. At least some of these unidentified pigments may have been formed from pheophorbide- $a$ during preparation for TLC. Not all the light absorption at $400 \mathrm{~nm}$ could be accounted for by either pheophorbide- $a$ or any of the other green pigments observed on the TLC. The ratio of absorbances at $4 \mathrm{r} 2 \mathrm{~nm}$ and $668 \mathrm{~nm}$ of pheophorbide- $a$ was approximately $2 \cdot 4: 1$, as shown in Fig. $\mathrm{I}$.

\section{LPC pigments}

The pigment compositions of X-Pro, lucerne LPC, and ryegrass LPC were markedly different, as shown by TLC examination of the acetone extracts. These differences were not evident from the appearance of the concentrates; lucerne LPC and ryegrass $\mathrm{LPC}$ were deep, brilliant green, whereas $\mathrm{X}$-Pro was a dull greenish yellow. The acetone extracts of the ryegrass LPC and the lucerne LPC gave similar absorbance values and similar gross visible-light absorption spectra. TLC examination indicated, however, that most of the chlorophyll-derived pigments of lucerne LPC were in fact chlorophyllides and pheophorbides, whereas the ryegrass LPC contained chlorophyll- $a$ and $-b$ and the two pheophytins; only small amounts of pheophorbides and chlorophyllides were present in the ryegrass LPC.

$\mathrm{X}$-Pro had a lower content of extractable pigments and the principal component was pheophorbide-a. The amount (Table 2) was very much less than for lucerne $\mathrm{LPC}$, but more than for ryegrass LPC.

\section{DISCUSSION}

Lucerne-protein concentrates contain at least one substance which produces severe photosensitivity when included in the diet of albino rats. The results suggest that the active substances may be pheophorbides, or perhaps chlorophyllides since it is known that the latter are converted into the former under the experimental conditions used. These pigments are derived from chlorophylls by removal of the phytyl sidechain; perhaps these smaller molecules are, therefore, more readily absorbed through the intestinal wall. This hypothesis is supported by the observation that the blood plasma 
and liver of rats given lucerne LPC contained substantial amounts of pheophorbide- $a$ in addition to two or three other unidentified green pigments, possibly artifacts produced in the preparation of the samples. Further evidence that phcophorbides were the causative agents was the positive relationship between the concentration of these pigments in the various products tested and their photosensitizing capacity.

However, it was not clear why much more pheophorbide was present in the lucerne LPC than in the ryegrass LPC, especially as the conditions of preparation of the concentrates werc similar. It is likely that pheophorbides were formed more readily during preparation of the lucerne LPC, and this was probably due to the greater amount of chlorophyllase activity in lucerne leaves as shown by Arkcoll \& Holden (I973). The numerous but erratic field reports of 'trefoil dermatitis' among grazing animals must also be accounted for. To explain why chlorophyll breakdown products should be present in lucerne and other legumes but not in ryegrass, it will be necessary to study the activity and activation of chlorophyllase and other enzymes involved.

Since pheophorbides and related compounds may be responsible for the photosensitization of albino rats (and possibly other white animals) it becomes necessary to understand the conditions leading to their formation from chlorophyll, so that procedures can be devised to prevent the production of these undesirable substances during the preparation of the potentially very valuable LPC. Work is continuing on the nature, action and mechanism of formation of the photosensitizing agents. A study of the effect of illumination on other white-skinned animals given lucerne LPC is being undertaken.

We thank Messrs I. J. Warrington and C. G. Tunnicliffe of the Plant Physiology Division, DSIR, for supplying and defining the light source, and $\mathrm{Mr}$ M. Jos Brusse and Dr R. M. Allison for preparing the lucerne and ryegrass leaf-protein concentrates.

\section{REFERENCES}

Arkcoll, D. B. \& Holden, M. (1973). F. Sci. Fd. Agric. 24, 1217.

Bacon, M. F. (1965). F. Chromat. 17, 322.

Blum, H. F. (r94I). Photodynamic Action and Diseases Caused by Light. New York: Reinhold.

Clare, N. T. (1944). N.Z. Il Sci. Technol. 25, 202A.

Clare, N. T. (1952). Photosensitization in Diseases of Donestic Animals. Farnham Royal: Conmonwealth Agricultural Burcaux.

Done, J., Mortimer, P. H. \& Taylor, A. (1960). Res. vet. Sci. I, 76.

Hove, E., Lohrey, E., Lrs, M. K. \& Allison, R. M. (I974). Br. F. Nutr. 3T, r 47.

Perrin, D. D. (1958). Biochem. F. 68, 314.

Radeliff, R. D. (1964). Veterinary Toxicology p. 6r. Philadelphia: Lea \& Febiger.

Smith, J. H. C. \& Benitez, A. (1955). In Modern Methods of Plant Analysis Vol. 4, p. 142 [K. Paech and M. V. Tracey, editors]. Berlin: Springer-Verlag.

Strain, H. H. \& Svec, W. A. (1966). In The Chlorophylls p. 54 [L. P. Vernon and G. R. V. Seely, editors]. New York: Academic Press.

\section{EXPLANATION OF PLATE}

Lesions produced in a male albino rat exposed to simulated daylight for $4 \mathrm{~h} / \mathrm{d}$ for 3 weeks. The diet contained lucerne leaf-protein concentrate at a concentration of $160 \mathrm{~g} / \mathrm{kg}$ diet. 
British Fournal of Nutrition, Vol. 31, No. 2

Plate I

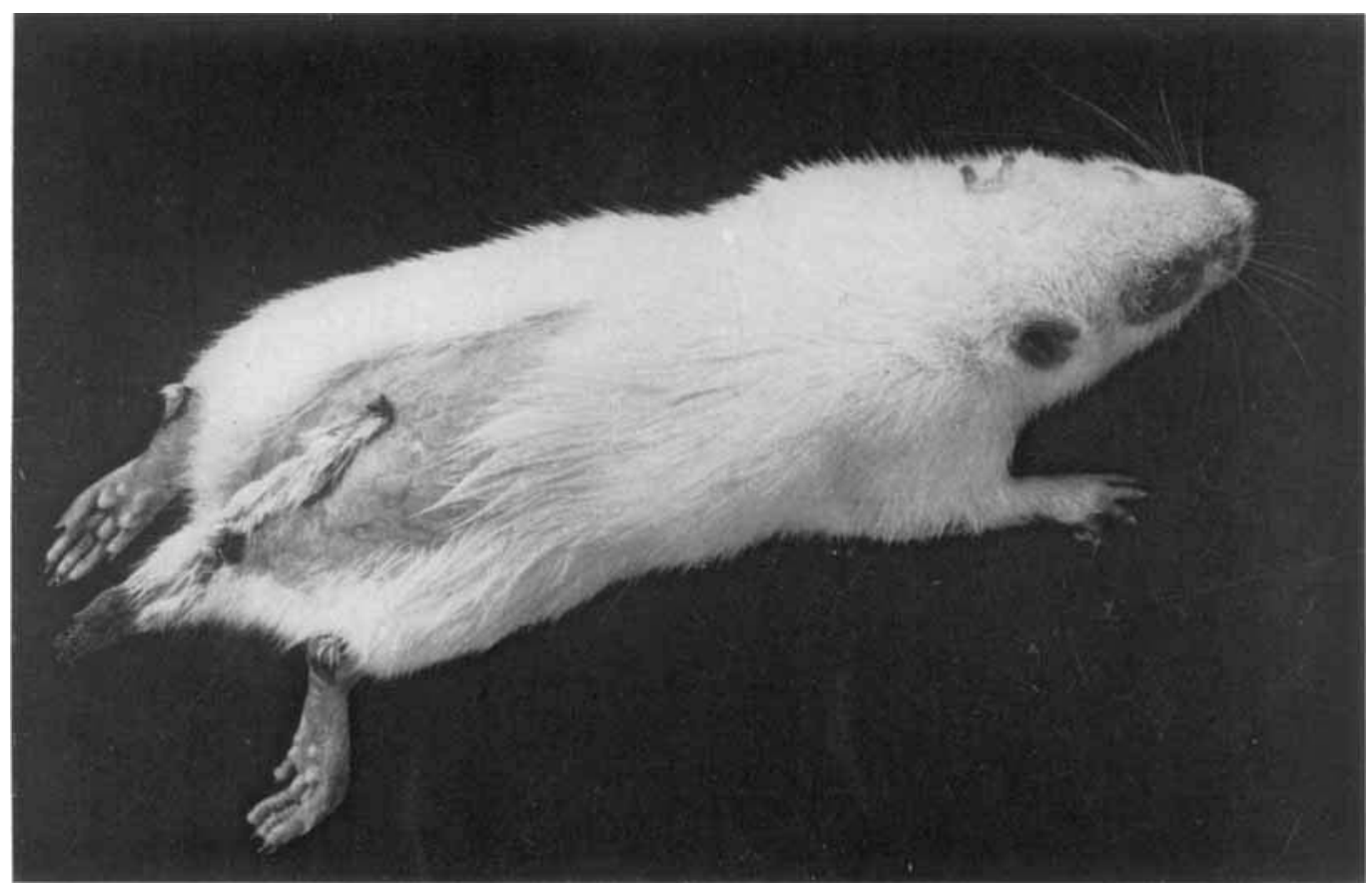

